\title{
Evaluating the Energy Requirements for Uganda: Case for Natural Gas
}

\author{
Muwanguzi Judah Bumalirivu Abraham*, Kaggwa Ronald, Werikhe Aaron, Ajidiru Rita, \\ Kandwanaho Jonan, Guloba Asuman, Muvawala Joseph
}

National Planning Authority, Science Department, Planning House, Kampala, Uganda

\section{Email address:}

abraham.muwanguzi@npa.go.ug (M. J. B. Abraham), ronald.kaggwa@npa.go.ug (K. Ronald), aaron.werikhe@npa.go.ug (W. Aaron), ajidiru.rita@npa.go.ug (A. Rita), jonan.kandwanaho@npa.go.ug (K. Jonan), asuman.guloba@npa.go.ug (G. Asuman), joseph.muvawala@npa.go.ug (M. Joseph)

${ }^{*}$ Corresponding author

\section{To cite this article:}

Muwanguzi Judah Bumalirivu Abraham, Kaggwa Ronald, Werikhe Aaron, Ajidiru Rita, Kandwanaho Jonan, Guloba Asuman, Muvawala Joseph. Evaluating the Energy Requirements for Uganda: Case for Natural Gas. International Journal of Energy and Environmental Science. Vol. 6, No. 4, 2021, pp. 68-77. doi: 10.11648/j.ijees.20210604.11

Received: May 24, 2021; Accepted: August 4, 2021; Published: August 23, 2021

\begin{abstract}
About 89 percent of Uganda's total primary energy consumption is generated through biomass. With the country aspiring to become an upper middle-income country by 2040, the total energy requirement is estimated to be 41,738 MW. Currently, 2,000 MW are being produced and the energy mix is dominated by biomass. With a population projected to be 85 million by 2040, there is an urgent need to increase on the generation capacity and diversify and introduce new alternative renewable sources of energy supply especially at the household level. This study was conducted to assess the extent of energy requirements and usage in the country and challenges that need to be addressed to enable the country transition to clean, more sustainable energy sources, with the focus on natural gas. The overall aim was to identify potential demand for natural gas and readiness for its use in the industry and household level. 227 households were visited and the top 25 energy consuming companies. It was discovered that the average LPG consumption per capita is $0.2-0.5 \mathrm{~kg} / \mathrm{year}$ compared to other sub-Sahara countries with an average LPG per capita consumption of $3 \mathrm{~kg} /$ year. Even though $22 \%$ of the population can afford LPG at the household level, only $0.8-1 \%$ use it due to negative attitude, safety concerns, difficult access and the high initial cost of purchasing the cylinders. All industrial stakeholders are eager and ready to take on natural gas to meet their energy needs as long as the cost/benefit analysis is favourable. The natural gas that will be required to produce 550,0000 tpa of liquid steel by 2024 will be 165-176 million $\mathrm{Nm}^{3}$ per year. The most favourable source of supply of natural gas to Uganda is from Tanzania.
\end{abstract}

Keywords: Sustainability, Industrial and Economic Development, LPG, Iron and Steel, National Planning Authority, NPA, Uganda

\section{Introduction}

Uganda is richly endowed with abundant energy resources that are fairly distributed throughout the country; hydro, biomass, solar, geothermal, peat and fossil fuels. Nonetheless, Uganda's energy consumption is among the lowest in the world. It is among the countries with the lowest levels of electricity development, with electricity access estimated at 20 percent of the population. Furthermore, it has the lowest per capita electricity consumption at $100 \mathrm{kWh}$ far below the sub-Saharan Africa average of $552 \mathrm{kWh}$ and the global average of 2,975 $\mathrm{kWh}$, according to the World Bank Development Indicators [1].
The energy resource potential of the country includes an estimated 2,000 MW of hydro power, $450 \mathrm{MW}$ of geothermal, 460 million tons of biomass standing stock with a sustainable annual yield of 50 million tons, an average of 5.1 $\mathrm{kWh} / \mathrm{m}^{2} /$ day of solar energy and about 250 million tons of oil equivalent of peat [2]. In addition, an estimated amount of 6.5 billion barrels of crude oil was discovered in the western part of the country, of which only 1.4 billion barrels are commercially recoverable. The country is also known to have nuclear energy potential with the exploration for radioactive materials in Uganda having started as far back as 1949 [3]. Currently, according to the Ministry of Energy and Mineral 
Development, it is indicated that Uganda has about 52,000 square $\mathrm{km}$ of uranium deposits, though the actual quantification of the resource has not yet been done.

Uganda has a total primary energy consumption of 772 PJ [4]. Biomass is the most important or used source of energy for the majority of the Ugandan population. About 89 percent of the total primary energy consumption is generated through biomass, which can be separated into firewood (78.6 percent), charcoal (5.6 percent) and crop residues (4.7 percent) $[4,2]$. Electricity is contributing only 1.4 percent to the national energy balance while oil products, which are mainly used for vehicles and thermal power plants, account for the remaining 9.6 percent, Figure 1. LPG, imported via Mombasa (Kenya) or Dar-es Salaam (Tanzania) port, consumption contributes less than 1 percent to the total primary energy.

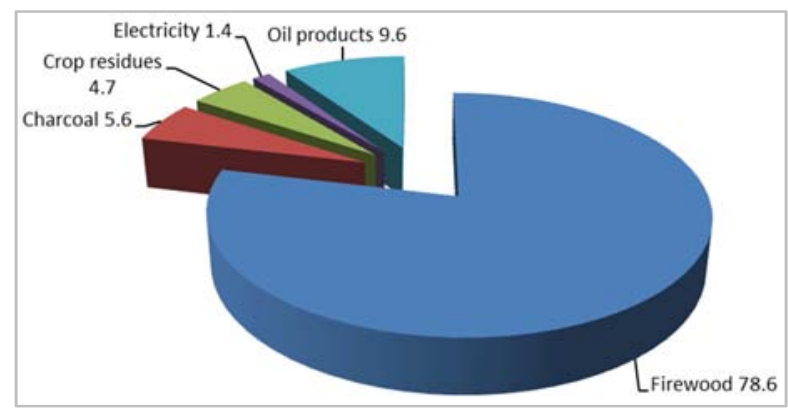

Figure 1. Primary energy consumption for Uganda.

High demand for wood fuels used inefficiently has resulted in overuse and depletion of forests. From 1990 to 2010, the forested area decreased from $49,240 \mathrm{~km}^{2}$ down to $29,880 \mathrm{~km}^{2}$. This means that over a 20 -year period, more than $19,360 \mathrm{~km}^{2}$, equalling 39 percent of the existing forest cover, disappeared $[5,6,7]$. In 2012, 14.1 percent of Uganda's land area was covered with forest but it presently stands at 12.4 percent. The pressure on land has been increased by the increasing population, growing at a rate of 3 percent per year, according to the Uganda Population and Housing Census of 2014, and further aggravated by the influx of refugees running from the instabilities in the region.

However, the recent State of the Environment Report (2018-2019) indicated that although all-natural forests have experienced a strong decline in the past decades, plantation forests registered an increment between 2010 and 2017 from 3 percent to 8 percent. Given this trend therefore, there is a potential to meet the future demand for wood.

As Uganda aims to become an upper-middle income country by 2040 [8], there is need to change the energy mix towards increasing the utilization of clean renewable energy sources, particularly for large industrial processes. This will go a long way in enhancing sustainability of the industrialisation agenda. Whilst hydro-electric power (a renewable energy source) accounts for 78.8 percent [9] of Uganda's energy mix, it is highly susceptible to the effects of climate change. This calls for exploration of other renewable climate change resilient energy technologies.

In 2003, oil and gas reserves were discovered in the
Albertine region in Western Uganda. Additionally, gas reserves were discovered in the neighbouring countries of Tanzania in 2003 and 2006 and in Rwanda in Lake Kivu in 2008. With the discovery of natural gas in Uganda and the neighbouring countries, there arose an opportunity for Uganda to develop its natural gas industry and benefit from internal or external (within the East Africa Community) gas reserves.

The Uganda National Oil Company (UNOC) reports the associated gas established in the country to date to be about 170 billion cubic feet (bcf) while the non-associated gas is estimated at about 500 bcf [10]. In Tanzania, the Petroleum Development Corporation (TPDC) puts the onshore and offshore gas reserves in Tanzania at 57 trillion cubic feet [11]. On the other hand, the gas reserves in Lake Kivu are measured at 1.942 trillion cubic feet [12].

With the continued depletion of Uganda's forest cover mainly due to the large amount of biomass used as an energy source for the majority of Uganda's population, the Government has prioritized development of the natural gas industry to provide a cleaner, safer and more environmentally friendly source of energy for the population. This study was conducted to assess the extent of energy requirements and usage in the country, perceptions on the various energy types, and challenges that need to be addressed to enable the country transition to clean, more sustainable energy sources, with the focus on natural gas, both in the domestic and industrial sector.

\section{Methodology}

It is important to note that whereas the study objective was to identify potential demand for natural gas and readiness for its use, there is currently no consumption of natural gas in Uganda and therefore statistics for consumption of other fuels were used; liquid petroleum gas (LPG), heavy fuel oil (HFO), coal, petroleum coke (petcoke) and kerosene, to project Uganda's natural gas demand.

Desktop review of documents relating to natural gas demand supply and infrastructure was carried out. A domestic household fuel consumption survey was conducted in several suburbs of varying income levels (low, middle and upper) around Kampala City, the capital of Uganda, and a total of 227 households were visited/surveyed. To establish the actual and potential demand for natural gas in the industrial sector, the top 25 large industrial energy consumers were visited/surveyed. The major aim of both visits was to ascertain the types of energy sources being used to meet the energy needs and at the same time establish the willingness of the users to switch to cleaner fuels like natural gas. Additionally, the suppliers and distributors of LPG were also visited plus the government agencies responsible for the energy sector.

Assessment of existing infrastructure visa-vie the necessary infrastructure to enable gas utilisation both in domestic and industrial settings was done so as to determine readiness for natural gas use. Furthermore, an analysis of the possible sources of supply for natural gas to Uganda's market was done; between three option of Lake Kivu (Rwanda), Tanzania and Albertine Region (Uganda) basing on existing and required infrastructure, 
available quantities, required investment, respective country plans and distance to the proposed site of the anchor project (iron smelting plant) in Uganda.

\section{Results and Discussion}

\subsection{Status of Uganda's Gas Demand}

Whereas Uganda has natural gas reserves in the Albertine region, this gas has not yet been extracted for either industrial or domestic use. Consequently, there is no natural gas supply into the Ugandan market and the gas demand needs are being met by liquefied petroleum gas (LPG) imported into the country. Figure 2 shows the trend of importation of LPG over the years [13].

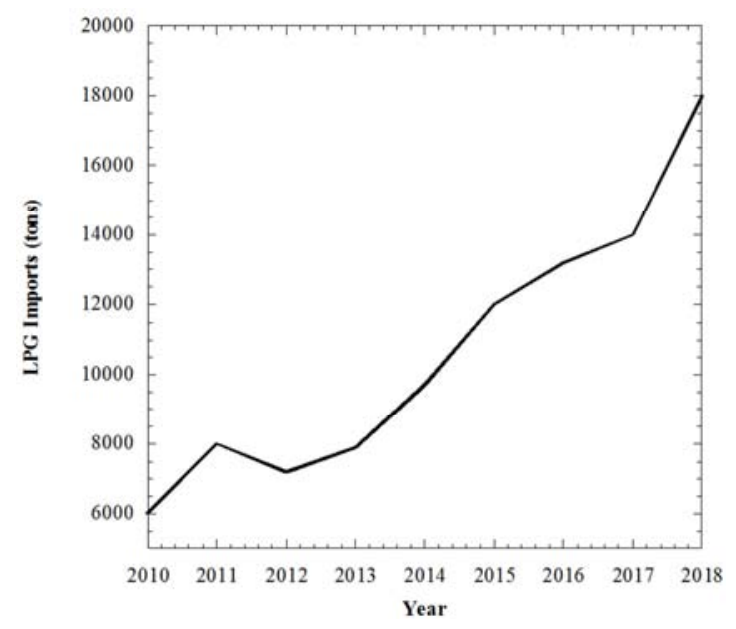

Figure 2. Imports of LPG for Uganda.

It can be noted from Figure 2 that there has been a steady increase in the amount of LPG imported into the country since 2010 and currently stands at about 18,000 tons. There was a slight levelling out in imports between 2015 and 2016, which was attributed to the introduction of Value Added Tax (VAT) on LPG and LPG cylinders by government, but the curve picked up there after, following the removal of VAT a few years later.

The information collected during stakeholder engagement with suppliers and distributors of LPG showed that the potential gas demand market in Uganda is steadily increasing though consumption remains low, compared to regional figures. The total LPG consumption is $14,000-15,000$ tons per annum (tpa). The average LPG consumption per capita is $0.2-0.5 \mathrm{~kg} /$ year compared to other sub-Sahara countries with an average LPG per capita consumption of $3 \mathrm{~kg} /$ year [2]. This accounts for $0.8-$ 1 percent of the population, even though statistics have shown that 22 percent of the population can afford to use LPG. The main reason given for this mismatch is the negative attitude towards LPG use, in that, many households believe that LPG is not a safe fuel source. Additionally, it was highlighted that it is difficult to access LPG compared to the other fuels such as firewood and charcoal and the initial costs including the gas cylinder are high.

In 1994, LPG usage in Uganda was standing at 0.5 percent of the population, compared with the current consumption of $0.8-1$ percent in 2019 [13]. Essentially, there has not been any significant change over the last 20 years. On the other hand, there is a steady increase in charcoal consumption nationwide. Currently, per capita consumption for charcoal is about UGX 8,000 whereas the per capita consumption for LPG is about UGX 1,100 [4, 14].

Among the indicators considered in assessing for gas demand were the number of market players. Over the years, the number of importers and distributors of LPG has been on the rise. Despite the under-consumption LPG figures, there were 19 new entrants into the LPG supply market between 2015 - 2019. Currently, there are 25 players (suppliers) in the Ugandan LPG market. However, there also exist LPG black market suppliers who are refilling cylinders without any safety precautions being considered. There is no LPG regulation in Uganda and some players are not abiding by Health Safety Environment and Community (HSEC) requirements, which has led to a compromise in safety and unfairness in the market. Furthermore, Government interventions in LPG pricing have been ad hoc and inconsistent, introducing and removing VAT without picking lessons to inform future actions. For instance, in 2006, LPG was VAT exempted but this did not benefit consumers or the environment partly due to the oligopolistic nature of the LPG market. VAT of $18 \%$ on LPG was reintroduced by the 2013/14 budget but in June 2020 government again scrapped it. These fluctuations affect the marketing of LPG as reliable alternative source of fuel.

Overall, the LPG national consumption is largely in the industrial sector which consumes 40 percent while the domestic sector consumes 30 percent, mainly in $3 \mathrm{~kg}$ and $6 \mathrm{~kg}$ cylinders, and the commercial sector (like schools, hospitals) which consumes 30 percent mainly in $45 \mathrm{~kg}$ cylinders.

Price is a main determinant in the choice of a fuel source. Gas demand in Uganda is in direct competition with several other fuel sources including kerosene, diesel, charcoal, petroleum coke and HFO. Figure 3 shows the changing prices for the different fuel over the years.

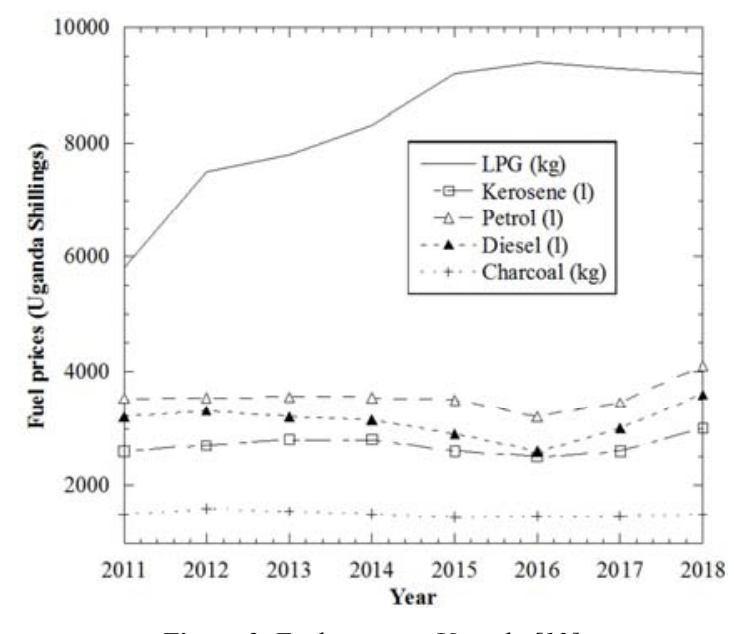

Figure 3. Fuel prices in Uganda [13].

Figure 3 shows that the price of LPG is averagely twice the price of substitute fuels in Uganda specifically, charcoal, and this greatly hinders its acceptance as an alternative fuel.

To assess the determinants of LPG price on the Ugandan market, the components that go into its price were analysed 
by percentage. These were found to include; the international crude oil price storage costs, taxes, bulk transportation costs, filling costs and margins set by the dealers, distributors and retailers, Table 1 . The global international LPG price that was considered is the average world price.

Table 1. Cost components of LPG in Uganda.

\begin{tabular}{lll}
\hline Item & USD/ton & $\begin{array}{l}\text { Percentage of } \\
\text { total price }\end{array}$ \\
\hline Global price [27] & 822.76 & 31 \\
Shipping and bulk transport to Kampala & 200.00 & 7 \\
Taxes (18 percent) & 148.10 & 6 \\
Filling, storage, operations and margins & $1,522.62$ & 56 \\
Final retail price $^{1}$ & $2,668.48$ & 100 \\
\hline
\end{tabular}

The biggest cost component of the LPG price in Uganda is retained by the LPG suppliers and distributors.

\subsection{Domestic and Industrial Energy Needs}

In determining the potential demand for natural gas in Uganda, industrial and domestic entities were surveyed. The fuel sources used in most industries were found to be biomass, heavy fuel oil, coal and liquefied petroleum gas. In some rare cases, electricity was used for heating requirements albeit in small amounts. Discussions with the industrial stakeholders revealed that these operational requirements can be met more efficiently and probably more cheaply by use of natural gas. On the other hand, the major source of fuel in households is biomass.

\subsubsection{Domestic - Household Fuel Consumption Survey}

Uganda's main application for gas as a source of fuel, at the domestic level, is cooking and water heating. In analysing the survey results, the parameters considered included; main cooking fuel used by each household, alternative cooking fuel used by each household, willingness to use liquefied petroleum gas, challenges experienced in using and switching to LPG, challenges experienced in using charcoal and sentiments towards charcoal usage on Uganda's climate. The findings are presented in Figures 4 to 8.

Analysis of the results revealed that of the seven suburbs visited, over 70 percent use charcoal as the main cooking fuel, Figure 4. LPG was the second most used source of cooking fuel, with 20 percent of the households visited accounting for this.

Figure 5 shows that the majority of the households visited had no alternative cooking fuel, 54 percent, with charcoal serving as the alternative cooking fuel for 12 percent of the households while paraffin and firewood followed at 11 and 8 percent, respectively.

Whereas charcoal was widely used as the main and alternative cooking fuel in most households surveyed, majority of the households using charcoal, as highlighted in Figure 4, expressed disadvantages to its use including: high cost -41 percent; health concerns such as cough, flue and poor hygiene -15 percent; and delay in cooking -12 percent, Figure 6.

\footnotetext{
${ }^{1}$ Price per ton calculated based on LPG refilling retail price in the Ugandan market.
}

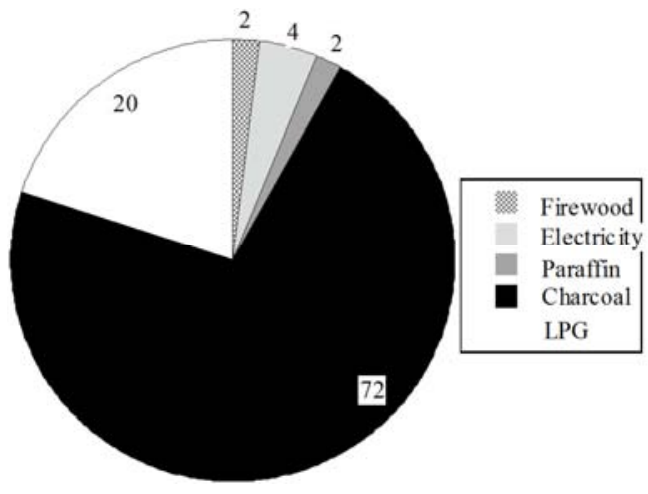

Figure 4. Fuel usage at the household level.

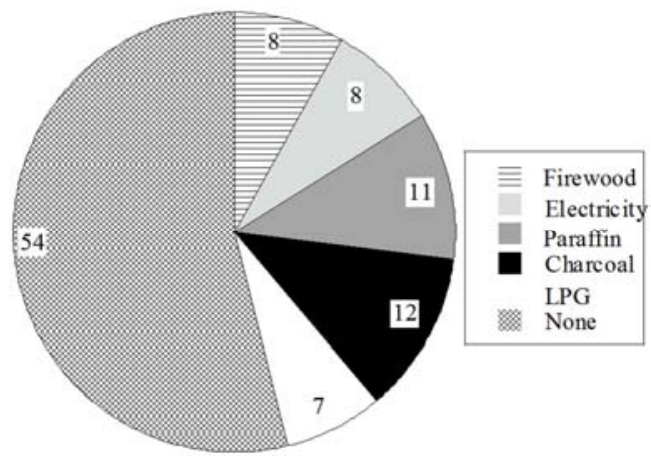

Figure 5. Alternative sources of fuel at the household level.

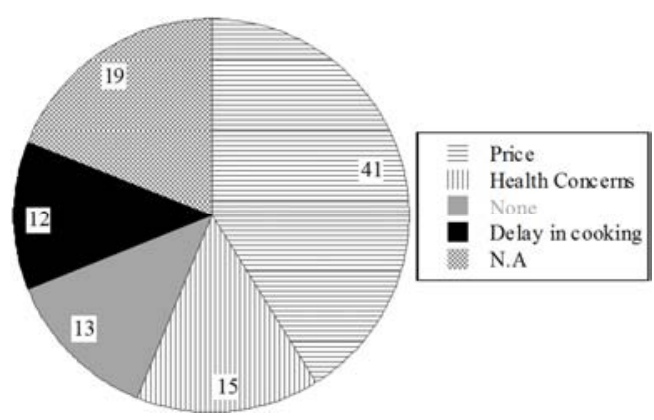

Figure 6. Challenges to charcoal use at the household level.

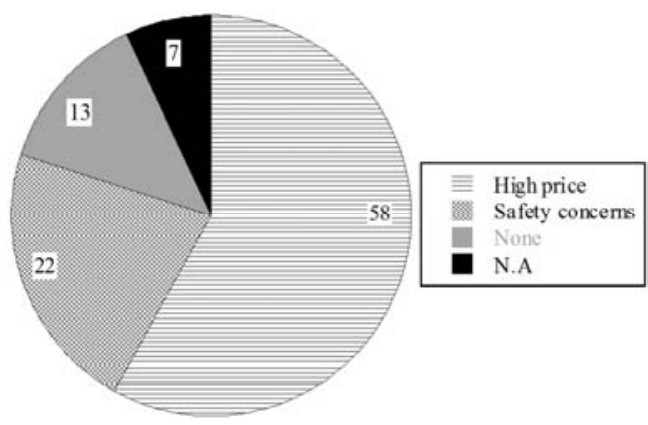

Figure 7. Challenges to LPG use at the household level.

In the upper income suburbs visited, LPG is the predominantly used source of fuel for cooking while in the middle-income suburbs visited, LPG is the main alternative source of cooking fuel. 86 percent of the respondents indicated their interest and willingness to switch to LPG as their main source of cooking fuel. However, they highlighted several hindrances, Figure 7, to the switch to LPG usage among which 
include; high price of LPG - 58 percent, safety concerns due to fears of explosion of LPG cylinders - 22 percent, and difficulty in accessing it, especially as compared with charcoal.

The results from the survey indicate that there is an overall readiness of the domestic sector to switch from charcoal to an alternative source for cooking fuel. Moreover, as indicated in Figure 8, 53 percent of the respondents believe that charcoal usage is causing deforestation while 22 percent believe that continued charcoal usage will adversely change the climate of Uganda. This implies that the use of charcoal is not because of choice, but the better alternatives are not affordable.

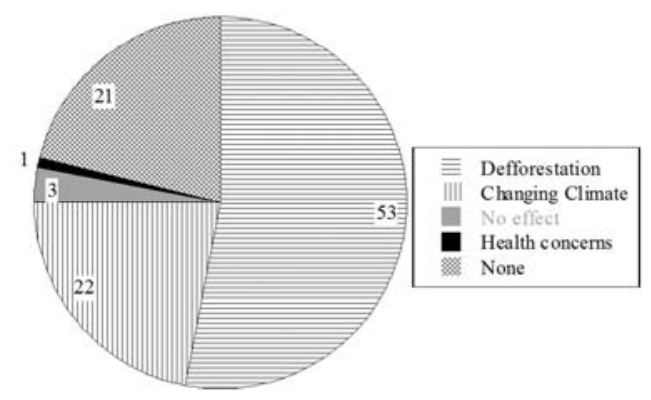

Figure 8. Opinion on charcoal use and its effect on Uganda's climate.

\subsubsection{Industrial - Gas Demand Survey}

In the industrial sector, energy is needed for a number of applications including heating, drying, lighting, vehicle propulsion, among others and natural gas can be used as a source of supply. Information collected shows that industrial stakeholders are eager and ready to take on natural gas to meet their energy needs so as to benefit from the production advantages associated with its usage. However, it was noted that the cost/benefit analysis needs to favour a switch to natural gas to enable industries have an economic conversion of their production lines to natural gas usage.

In all the industries visited, the industrial heating applications are being met by heavy fuel oil, biomass, LPG, hazardous waste and coal. The predominant source for industrial heating amongst the industries visited is biomass. All the industries visited expressed concern about the detrimental effects on the overall climate of Uganda due to the continued use of biomass in their operations. Moreover, the industries are faced with a continued shortage of biomass and the companies have resorted to importing biomass to meet their production requirements.

The industries involved in the food industry expressed high enthusiasm for use of natural gas in their applications due to the increased production efficiency that can be attained as a result of direct heating in their production processes. Besides the efficiency gains, this conversion would also go a long way in implementing newly adopted National Green Manufacturing Strategy.

HFO is particularly challenging in industrial heating due to its varying quality. HFO requires high maintenance because it depreciates rapidly leading to low calorific values. Similarly, coal is affected by varying qualities that affect production levels. Burning poor quality coal produces ash and oil discharge that clogs nozzles resulting into production delays.
The industries visited are considered large scale electricity consumers and some of them have dedicated power lines to their production plants. Discussion from the industrial site visits showed that there is a challenge of high-power tariffs and yet its unreliable. The industries expressed concern about the continued power outages that lead to production losses.

To counteract the power outages some companies have installed large diesel generators to ensure stable and continued power supply. However, diesel costs have greatly increased production costs thereby making their products less competitive. Some industries have incurred further expenses to install uninterruptible power supply (UPS) units to protect their equipment from damage due to power outages.

Given the high cost of electricity in Uganda and the unreliability of power supply, all the industries visited (25) are open to the option of natural gas use to meet their energy needs. This will however depend on the cost of supply of natural gas compared to alternative sources of electricity.

In the food industry, diesel/petroleum operated vehicles cannot be used in the production process due to the fumes generated by burning fuel in vehicle engines. Consequently, electrical or gas vehicles are used in the production processes. The industries however reported that electrical vehicles are not viable due to the need for frequent recharging of the batteries.

Presently, the food industry uses LPG in the production forklifts. Compressed natural gas $(\mathrm{CNG})$ vehicles provide a cheaper alternative to LPG vehicles and the industries are open to benefit from this saving in production cost.

\section{Analysis of Possible Sources of Natural Gas for Uganda's Supply}

The government of Uganda intends to introduce natural gas as a source of energy supply, in order to diversify its energy mix. The reduction of the existing iron ore for the production of iron and steel to meet the construction demands in the country is considered as the anchor project for the natural gas supply. Natural gas is used both as an energy source and a reducing agent in iron ore reduction. To supply the proposed direct reducing plant (DRP), a source of natural gas that can last several decades is necessary so as to ensure continued supply over the mine life estimated at over 50 years. The government also intends for natural gas to be used for domestic and other industrial applications.

Three supply options available to Uganda are; natural gas from the Uganda Albertine region, natural gas from Lake Kivu in Rwanda and natural gas from Tanzania. Several factors were considered in determining the supply source of natural gas to meet Uganda's energy demand requirements; cost of supply route, duration of supply (size of gas reserves), reliability of supply, security, construction requirements, and problem of negotiating export contracts $[15,16]$.

\subsection{Uganda, Albertine Region}

Uganda's natural gas reserves are both associated and non- 
associated. The Ministry of Energy and Mineral Development (MEMD) reports the recoverable natural gas reserves as 672 billion $\mathrm{ft}^{3}$ of which 500 billion $\mathrm{ft}^{3}$ is nonassociated gas and 173 billion $\mathrm{ft}^{3}$ is associated gas.

Non-associated gas, which is found in reservoirs or gas caps, can be extracted separately from oil if the gas reserve is a gas cap on-top of the oil reserves [17]. Uganda's non-associated gas reserves will be produced independently. The associated gas reserves which are dissolved in the crude oil will only be produced during the extraction of the crude oil and after exhaustion of the crude oil reserves when the associated natural gas is no longer needed to provide pressure in the reservoir to enable free flow of the crude oil through the drill-hole.

Information from Uganda National Oil Company and Total E\&P Uganda, states that the non-associated gas produced from Uganda's natural gas reserves will be used to generate electricity to run the crude oil upstream operations. Given the electricity requirement for the crude oil upstream operations, the non-associated natural gas reserves are expected to last up-to 8 years.

According to China National Offshore Oil Company (CNOOC), the associated gas reserves that will be produced during crude oil drilling operations will be used for manufacture of liquefied petroleum gas so as to meet the government needs of fuel supply for domestic use.

\subsection{Tanzania, Mnazi Bay \& Songo Songo Island}

The Tanzania natural gas reserves were commercialised in 2004 and 2006 for Songo Songo Island and Mnazi Bay respectively. The Tanzania Petroleum Development Corporation (TPDC) puts the natural gas reserves at 57 trillion $\mathrm{ft}^{3}$ although offshore exploration is continuing [11].

The TPDC indicates that the natural gas being produced is used for power generation, industrial production and domestic consumption in selected regions. This consumption accounts for only 10 percent of the production capacity and the TPDC is making plans to extend the natural gas supply infrastructure to attract new industries.

TPDC estimates that Tanzania's gas reserves are large enough to cover Tanzania's gas requirements and make Tanzania the next natural gas hub in Africa. The extent of Tanzania's gas reserves is further confirmed by the onshore and offshore exploration activities being conducted by industrial leaders; Royal Dutch Shell, Statoil, Exxon Mobil and Ophir Energy in a bid to construct a liquefied natural gas (LNG) plant for exportation of gas.

In May 2016, the government of Tanzania, in a bid to extend the natural gas infrastructure to its northern part, expressed interest in selling natural gas to Uganda as a means of increasing the economic viability of the project. Subsequently, in August 2018, both governments signed a Memorandum of Understanding to develop a natural gas pipeline that will potentially run parallel to the crude oil pipeline that will be constructed to export crude oil from Hoima, Uganda to Tanga in Tanzania. The proposed pipeline route would start in Tanzania at Tanga, go through Mwanza and then loop around Lake Victoria and enter Uganda at Mtukula border and go through
Masaka and terminate in Kampala (the capital city), a distance of $1,770 \mathrm{~km}$, Figure 9 [18].

\subsection{Rwanda, Lake Kivu}

Lake Kivu is a 1,040 square-mile lake located at the border of Rwanda and the Democratic Republic of Congo and is shared equally between the two countries. The lake is between two volcanic regions in the Great Rift valley and extends to depths of up-to $485 \mathrm{~m}$ and is consequently a meromictic lake (layers of water do not intermix) with stratified layers [19]. From deep underground, magma heated springs release carbon-dioxide into the bottom layers of the lake. There are microbes that convert the carbon-dioxide to methane. Both the dissolved carbon-dioxide and methane are kept in solution by the pressures at depth in the lake. Information from Martin Doevenspeck (2007) and the Republic of Rwanda, Ministry of Infrastructure put the amounts of carbon-dioxide and methane at $250-300 \mathrm{~km}^{3}$ and $55-60 \mathrm{~km}^{3}$ respectively.

Lake Kivu is also known as a "killer lake" due to the possibility of a limnic eruption (dissolved carbon-dioxide erupts to the surface) similar to limnic eruptions in Cameron in 1984 on Lake Monoun and in 1986 on Lake Nyos [20], which were saturated with $\mathrm{CO}_{2}$ and both led to the deaths of close to 1,800 people due to asphyxiation. This reputation as a "killer lake" is founded due to the regular volcanic discharges and large magnitude seismic events in the region that can cause a lake overturn.

To minimize the risk of a limnic eruption and utilize the methane resource, the Rwandese government set up methane extraction platforms that extract dissolved methane and use the same to generate electricity. The first methane extraction platform went online in 2015 and produced 26.2 MW [21]. The country has since developed more platforms and intends to use extracted methane to produce $700 \mathrm{MW}$ of electricity for export purposes. The country also intends to produce bottled gas, fertilizers and other industrial inputs from the methane in Lake Kivu.

According to the Ministry of Infrastructure, Lake Kivu has a capacity to generate 120 to 150 million $\mathrm{m}^{3}$ of methane annually representing a generation capacity of $90-130 \mathrm{MW}$ of electricity. Of the $55 \mathrm{~km}^{3}$ of methane, it is estimated that $40 \mathrm{~km}^{3}$ are economically extractable. At a production rate of $700 \mathrm{MW} /$ year that exceeds the methane self-regeneration capacity of the Lake, the methane resource is estimated to last 55 years.

Despite the extraction of methane, there is still the risk of $\mathrm{CO}_{2}$ concentration in the lake. While methane is extracted for power generation, the $\mathrm{CO}_{2}$ is pumped back into the lake. Given the size of the lake, drawing out $\mathrm{CO}_{2}$ from the lake is a major engineering challenge.

\subsection{Analysis of the Three Sources of Natural Gas}

Three different factors were considered to determine the most suitable source of supply for natural gas; define the gas pipeline route required to transport the natural gas from the three potential sources (Albertine Region, Tanzania and Lake 
Kivu in Rwanda):

1) Realize a new gas pipeline that directly transports the gas to the proposed steel works industrial park in the south western part of the country. The selected option aims at a pipeline length that is less than the other two options.

2) Realize a new gas pipeline along the same corridor as the East Africa Crude Oil Pipeline (EACOP) pipeline. With this option, the time for realization could be reduced since a part of the work done for the realization of the oil pipeline will be completed.

3) Realize a new pipe line that goes through some industrial parks planned in the third National Development Plan (NDP III) [1]. With this option, the gas could also be exploited by industries present in other industrial parks.

The length indications of the main sections of the route for the three possible sources of natural gas are discussed in the following section Figure 9.

\subsubsection{Option 1: Uganda, Albertine Region}

There are three possible routes to transport the natural gas to the proposed steel works industrial park (Rubanda district) from the Albertine Region (Hoima district):

a) Going through industrial parks of Fort Portal, Kasese, Bushenyi and Kabale. The lengths of the different sections are:

1) from Hoima to Fort Portal $(145.8 \mathrm{~km})$

2) form Fort Portal to Kasese $(44.4 \mathrm{~km})$

3) from Kasese to Bushenyi $(65.8 \mathrm{~km})$

4) from Bushenyi to Kabale $(99.7 \mathrm{~km})$

5) from Kabale to the steel works industrial park (30 km)

The total length of the gas pipeline will approximately be 385 $\mathrm{km}$. The other costs associated with this option are linked to the fact that the pipeline passes through ecologically sensitive areas that are rich in biodiversity (protected areas). This requires extra caution to ensure safety and conservation of biodiversity some of which is endemic.

b) Along the oil pipeline corridor (EACOP pipeline) from Hoima to Rakai; going through industrial parks of Rakai, Mbarara, Bushenyi and Kabale. The lengths of the various sections are:

1) from Hoima to Rakai $(260 \mathrm{~km})$ - EACOP corridor

2) form Rakai to Mbarara (76.6 km)

3) from Mbarara to Bushenyi $(60.8 \mathrm{~km})$

4) from Bushenyi to Kabale $(99.7 \mathrm{~km})$

5) from Kabale to the steel works industrial park (30 km)

The total length of the gas pipeline will approximately be $527 \mathrm{~km}$.

c) A gas pipeline that directly transports the gas from Hoima to the proposed steel work industrial plant. With this option the total length of gas pipeline will approximately be $350 \mathrm{~km}$.

\subsubsection{Option 2: Tanzania, Mnazi Bay \& Songo Songo Island}

The government of Tanzania will deliver the natural gas to its border with Uganda in the north, at Mtukula. There are two possible routes to transport the natural gas to the proposed steel works industrial park (Rubanda district) from Uganda-Tanzania border: a) Going through industrial parks of Mbarara, Bushenyi and Kabale. The lengths of the different sections are:

1) from Uganda-Tanzania border to Rakai $(35 \mathrm{~km})$ EACCOP pipeline

2) from Rakai to Mbarara (76.6 km)

3) from Mbarara to Bushenyi $(60.8 \mathrm{~km})$

4) from Bushenyi to Kabale $(99.7 \mathrm{~km})$

5) from Kabale to Steel works industrial park $(30 \mathrm{~km})$

The total length of the gas pipeline is about $302 \mathrm{~km}$.

b) A gas pipeline that directly transports the gas from Uganda-Tanzania border to steel works industrial park; the total length of gas pipeline is approximately $180 \mathrm{~km}$.

Option 3: Rwanda, Lake Kivu

With this option, the total length of the gas pipeline will approximately be $100 \mathrm{~km}$ but it is important to note the following two aspects:

1) The Rwanda government has already decided to exploit the natural gas to produce electricity which will be shared by the government of Rwanda and Democratic Republic of Congo. Rwanda already has two companies that extract gas from Lake Kivu to power electricity plants in order to reduce the use of firewood and charcoal, the fuels most households and tea factories use,

2) At the present, there is no agreement between Uganda government and Rwanda government for the natural gas exportation to Uganda,

The main characteristics of the different natural gas sources are summarised in Table 2.

Table 2. Comparison of the different natural gas sources.

\begin{tabular}{|c|c|c|c|}
\hline Parameter & Uganda & $\begin{array}{l}\text { Lake Kivu, } \\
\text { Rwanda }\end{array}$ & Tanzania \\
\hline Amount of gas & 0.5 trillion $\mathrm{ft}^{3}$ & $\begin{array}{l}1.94 \text { trillion } \\
\mathrm{ft}^{3}\end{array}$ & $\begin{array}{l}57.3 \text { trillion } \\
\mathrm{ft}^{3}\end{array}$ \\
\hline $\begin{array}{l}\text { Total energy of the reserve } \\
\text { (PJ) }\end{array}$ & 541 & 2,100 & 61,990 \\
\hline Planned Utilization & $\begin{array}{l}\text { LPG, } \\
\text { Electricity } \\
\text { generation }\end{array}$ & $\begin{array}{l}\text { Electricity } \\
\text { generation, } \\
\text { LPG }\end{array}$ & $\begin{array}{l}\text { Electricity } \\
\text { generation, } \\
\text { LPG, }\end{array}$ \\
\hline Distance to $\mathrm{DRP}^{2}(\mathrm{~km})$ & $\begin{array}{l}350-527 \text { (it } \\
\text { depends on } \\
\text { selected } \\
\text { option) }\end{array}$ & 100 & $\begin{array}{l}180-302 \text { (it } \\
\text { depends on } \\
\text { selected } \\
\text { option) }\end{array}$ \\
\hline $\begin{array}{l}\text { Indicative Cost } / \mathrm{km} \text { of } \\
\text { piping }(\mathrm{M} €)\end{array}$ & 2.2.-2.8 & $2.2-2.8$ & $2.2-2.8$ \\
\hline $\begin{array}{l}\text { Projected lifespan under } \\
\text { current and planned use }\end{array}$ & 8 years $^{3}$ & 55 years $^{4}$ & 80 years $^{5}$ \\
\hline $\begin{array}{l}\text { Lifespan meeting Uganda's } \\
\text { industrial and domestic } \\
\text { demand }^{6}\end{array}$ & $\begin{array}{l}\text { Less than } 1 \\
\text { year }\end{array}$ & $\begin{array}{l}\text { About } 3 \\
\text { years }\end{array}$ & $\begin{array}{l}\text { About } 84 \\
\text { years }\end{array}$ \\
\hline $\begin{array}{l}\text { Potential for additional } \\
\text { reserves }\end{array}$ & Low & $\begin{array}{l}\text { Self- } \\
\text { regenerating }\end{array}$ & Low \\
\hline Associated risks & $\begin{array}{l}\text { Risk of limnic } \\
\text { eruption }\end{array}$ & $\begin{array}{l}\text { Not } \\
\text { applicable }\end{array}$ & $\begin{array}{l}\text { Not } \\
\text { applicable }\end{array}$ \\
\hline
\end{tabular}

\footnotetext{
${ }^{2}$ Plant location assumed to be Rubanda District, south western part of Uganda

${ }^{3}$ Gas to be used for electricity generation to power upstream crude oil operations

${ }^{4}$ Projected gas to power capacity of $700 \mathrm{MW}$

${ }^{5}$ Tanzania plans to have $10,000 \mathrm{MW}$ power capacity, assumption of 100 percent gas to power generation to meet $10,000 \mathrm{MW}$ capacity

${ }^{6}$ Uganda gas demand is compared against the different NG sources
} 
Overall, the costs associated with pipeline construction depend on many factors: the cost per km, which increases with the pipe size; existing land use for the proposed pipeline route; terrain and population density of the proposed route, among other factors. However, the largest pipeline costs are due to materials and labour (70-80percent). In Uganda, according to Uganda National Oil Company, the specific cost for the construction of the gas pipeline is approximatively EUR 2.2-2.8 million $/ \mathrm{km}$.

All available natural gas supply options to Uganda, have advantages and disadvantages and the decision is also strongly linked to the political aspects. The Tanzanian government is working towards distributing natural gas to the Tanzanian hinterland thereby connecting natural gas off-takers within Tanzania. It is expected that these several off-takers along the pipeline route will make the natural gas tariff to Uganda affordable and increase the viability of the natural gas pipeline. Additionally, Tanzania has an MoU with Uganda to develop a natural gas pipeline extending to Uganda through the northern part of Tanzania. The use of natural gas from Tanzania, therefore, seems to be the most appropriate option. Furthermore, the construction of the natural gas pipeline from Tanzania to Uganda can become an integral part of the oil pipeline project for transporting crude oil from the Albertine Region to Port of Tanga in Tanzania (Figure 9). Uganda's oil is rich of waxy compounds [22, 23] and it must be heated up to $65^{\circ} \mathrm{C}$ to be transported and natural gas energy could be used for this activity. However, the final price of natural gas to the Ugandan government will be influenced by the management and development cost of the lengthy natural gas pipeline across the 1,200 km territory in Tanzania. A pipeline management framework needs to be crafted to ensure competitive pricing of the natural gas especially within the Tanzanian territory.

\section{Natural Gas Demand: Actual Potential of Application and Future Demand}

\subsection{Potential Actual Natural Gas Demand}

In order to capture the potential and actual natural gas demand for both industrial and household sectors, the energy consumption was divided into two groups: 1) Industrial and Household and 2) Transport and other sectors.

The industrial and household sectors use coal, HFO, LNG, LPG, petcoke and kerosene. Moreover, 16 percent (5.8 PJ/year) of the total diesel import is also included in the industrial sector because it is used for power generation for several companies due to electricity shortfalls. The transport sector uses petrol, jet fuels and about 99 percent of the diesel imported.

In estimating the potential natural gas demand for industrial and household applications, the statistics used are liquefied petroleum gas imports into the country and import statistics of fuels that can be substituted with natural gas. Potential substitutes include LPG, LNG, HFO, coal, petcoke, biomass and 16 percent of the imported diesel.

The amount of kerosene imported stands at 56,072 $\mathrm{m}^{3}$ [24] and this fuel type was not applied to the study because much of the kerosene imported into Uganda is used for lighting which cannot be substituted by natural gas.

Table 3 [13] reports cost of import in millions of US dollar for LPG, LNG, Coal, HFO, petcoke and diesel used in industrial sector (16 percent of the total diesel imported).

Table 3. Imports for the various energy source supplies in Uganda (Energy Demand).

\begin{tabular}{|c|c|c|c|c|c|c|c|c|c|}
\hline & \multicolumn{9}{|c|}{ Cost of import in millions of US Dollar } \\
\hline & 2010 & 2011 & 2012 & 2013 & 2014 & 2015 & 2016 & 2017 & 2018 \\
\hline LPG & 6.80 & 9.82 & 10.60 & 11.24 & 11.98 & 7.69 & 7.96 & 9.36 & 13.30 \\
\hline LNG & 1.71 & 2.01 & 1.60 & 1.93 & 3.19 & 1.36 & 0.34 & 0.10 & 0.38 \\
\hline Coal & 0.01 & 7.27 & 1.77 & 4.19 & 2.88 & 2.98 & 2.26 & 4.29 & 4.91 \\
\hline $\mathrm{HFO}$ & 83.96 & 108.58 & 81.65 & 39.72 & 36.79 & 21.21 & 12.84 & 39.08 & 36.60 \\
\hline Petcoke & 0.004 & 0.001 & 0.011 & 0.025 & 4.694 & 3.123 & 1.814 & 3.954 & 3.570 \\
\hline Diesel & 68.5 & 96.1 & 90.6 & 90 & 95.2 & 64.6 & 50.7 & 65.6 & 88.3 \\
\hline
\end{tabular}

Table 4. Calorific value of fuel sources.

\begin{tabular}{|c|c|c|c|c|}
\hline Fuel source & & Quantity of fuel consumed & Unit Calorific value (MJ/kg) [28] & Total Gross Calorific Value (MJ) \\
\hline Coal [13] & & $56,251,831 \mathrm{kgs}$ & 25 & $1,406,295,775$ \\
\hline HFO [13] & & $65,581,279 \mathrm{kgs}$ & 40 & $2,623,251,160$ \\
\hline Biomass & Domestic and commercial & 39 Million tons of wood equivalent & 16 & $624,000,000,000$ \\
\hline [29] & Industrial & 6.4 Million tons of wood equivalent & 16 & $102,400,000,000$ \\
\hline LNG [13] & & $585,608 \mathrm{kgs}$ & 55 & $32,208,440$ \\
\hline LPG [13] & & $1,7902,197 \mathrm{kgs}$ & 49 & $877,207,653$ \\
\hline Petcoke [13] & & $22,051,900 \mathrm{kgs}$ & 34 & $749,764,600$ \\
\hline Diesel* $^{*}$ & Industrial applications & $126,263,222 \mathrm{kgs}$ & 44.4 & $5,606,087,075$ \\
\hline \multicolumn{4}{|c|}{ Total calorific value of the different fuel sources } & $737,694,814,703$ \\
\hline
\end{tabular}

*it included only the diesel used for industrial applications.

With the imported quantities, an estimated natural gas demand is made based on the calorific values of the various fuel sources. Industrial biomass consumption is used to estimate natural gas demand in the industrial sector. While it is assumed that LPG should be the primary fuel used to initially meet the domestic fuel needs, an equivalent figure is suggested for the domestic natural gas demand based on the calorific equivalent of the biomass consumed domestically. 
Fuels have varying calorific values based on the grade, quality and age. An average value is used in order to estimate the amount of potential actual natural gas demand for industrial and household sectors (Table 4).

Considering:

1) the calorific value of natural gas is $45 \mathrm{MJ} / \mathrm{kg}$

2) $1 \mathrm{~m}^{3}$ of natural gas produces $38.3 \mathrm{MJ}^{7}$

Therefore, it implies that $16,393,218$ tons or $19,260,961,219$ $\mathrm{m}^{3}$ of natural gas is required to meet the fuel requirement being currently met by coal, HFO, LNG, LPG, petcoke, biomass and diesel for industrial applications, annually.

\subsection{Natural Gas Utilization in Steelmaking Industry}

As per the Uganda government plans, the anchor project for the natural gas pipeline is steelmaking. Steelmaking involves different cycles such as heating, cooling, melting and solidification. It is a highly energy intensive industry. The reduction of energy consumption in this kind of industry is of a special concern. In general, energy savings can be achieved by cutting down direct energy consumption and increasing energy recovery.

Energy consumption in the different stages of steel production is about 70 percent for iron and steel production, 20 percent for rolling and 10 percent for other activities.

The main source of energy used in the steelmaking industry is chemical (fossil fuels) in integrated steel plants and electrical in Electric Arc Furnace (EAF) cycle.

The treatments that require the higher natural gas consumption are gas based direct reduction plant and reHeating furnaces.

\subsection{Source of a Reducing Agent}

Direct reduced plants (DRP), an alternative approach to iron making starting from iron ore, has been developed to overcome some of the difficulties presented by the conventional blast furnace approach. In the DRP the reduction of iron oxide is carried out by a mixture of $\mathrm{CO}$ and $\mathrm{H}_{2}$ at a temperature of about $750-950^{\circ} \mathrm{C}$. The reducing gas is produced by reformation of natural gas. The reformation is a partial oxidation of hydrocarbons. To enhance the reformation process, a catalyst (nickel) is normally used.

The utilization of natural gas to produce DRI with vertical furnaces is a proven technology at industrial scale. Currently, more than 70 million tpa of steel are produced with gas-based DRI processes, the major part being produced by Midrex process.

According to a feasibility study carried out by the National Planning Authority, NPA, (the national planning Agency) in 2019, the actual liquid steel production in Uganda (with induction furnace) is about 240,000 tpa and is estimated that it will reach 1,100,000 tpa by 2024 .

Since it not possible to convent coal based DRI processes (typically small size plants) to gas based DRI processes, an assumption can be made that there will be a gradual

\footnotetext{
${ }^{7}$ Natural Gas Vehicle Knowledge Base: Natural Gas.
}

transition to gas-based reduction and by 2024, at least 50 percent $(550,000$ tonnes) of the liquid steel will be produced using natural gas.

Considering that the average consumption of natural gas for the production of 1 ton of the DRI with vertical furnace (Midrex) is approximately $300-320 \mathrm{Nm}^{3}$ (SPT), the natural gas supply required to produce 550,0000 tpa by 2024 will be 165-176 million $\mathrm{Nm}^{3}$ per year.

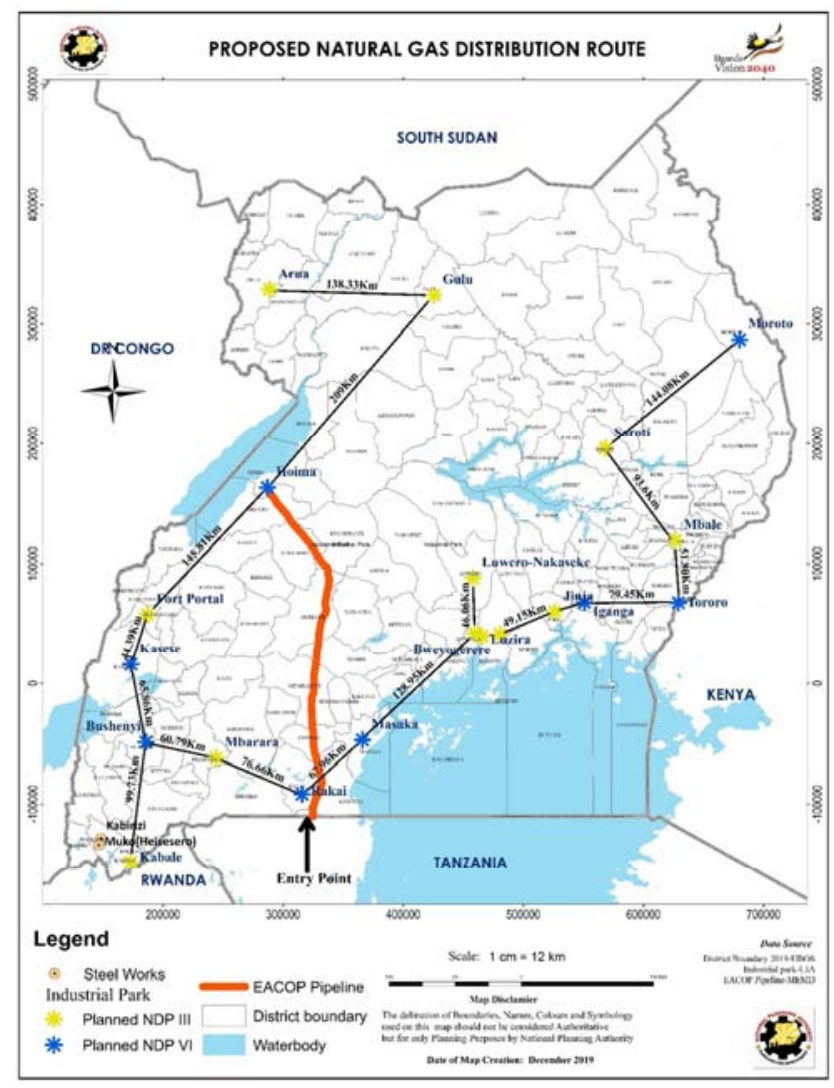

Figure 9. Proposed natural gas distribution plan.

\section{Conclusions}

The gas consumption per capita in Uganda is the lowest in East Africa and it has not increased in line with consumption levels of other traditional fuels. Whereas income levels have increased over the years and more people at the domestic level can afford to purchase LPG, the levels of gas consumption still remain low mainly due to safety concerns, price, affordability and accessibility. The industrial sector is well informed about the benefits of gas usage and is very welcoming of the switch for their industrial applications. It is acknowledged that there are negative environmental impacts associated with the current fuels. To ramp up gas consumption and make the natural gas pipeline more economically viable, Uganda should initially start by increasing LPG consumption and gradually shift to natural gas as the economy grows and infrastructure developments required for natural gas is put in place. Government should focus on domestic consumption of LPG so as to tackle environmental degradation. Analysis of the three different natural gas sources revealed that the most suitable source of gas supply in the 
Ugandan context is the utilization of natural gas from Tanzania. All in all, there is clearly demand for natural gas in Uganda but the infrastructure for its distribution in the country needs to be put in place. To scale up gas consumption in Uganda, it is necessary for the government to ensure that its affordable and accessible by providing the requisite infrastructure including its storage and packaging, reducing taxes on gas and gas equipment and also creating awareness on the benefits of gas usage.

\section{References}

[1] National Planning Authority, Third National Development Plan (NDPIII) 2020/21-2024/25, Kampala: National Planning Authority, 2020.

[2] K. O. Adeyemi and A. A. Asere, "A review of the energy situation in Uganda," International Journal of Scientific and Research Publications, vol. 4, no. 1, pp. 1-4, January 2014.

[3] International Uranium Resources Evaluation Porject, "IUREP Orientation Phase Mission: Summary Report - Uganda," The OECD Nuclear Energy Agency, Paris, 1985.

[4] Ministry of Water and Environment, "Uganda Woodfuel Overview,” World Bank, Kampala, 2019.

[5] F. I. B. Kayanja and D. Byarugaba, "Disappearing forests of Uganda: The way forward," Current Science, vol. 81, no. 8, pp. 936-947, 2001.

[6] Ministry of Water and Environment, "State of Uganda's Forestry," Ministry of Water and Environment, Kampala, 2016.

[7] J. Obua, J. G. Agea and J. J. Ogwal, "Status of forests in Uganda," African Journal of Ecology, vol. 48, no. 4, pp. 853 - 859, 2010.

[8] National Planning Authority, "Uganda Vision 2040," National Planning Authority, Kampala, 2013.

[9] Electricity Regulatory Authority, “Annual Corporate Report (2018/19),” Electricity Regulatory Authority, Kampala, 2019.

[10] Ministry of Energy and Mineral Development, "The oil and gas sector in Uganda," Ministry of Energy and Mineral Development, Kampala, 2019.

[11] K. B. Obadia, Z. Lingling, W. G. Mushi, S. L. Suntu and M. G. Gregory, "An overview of the natural gas sector in Tanzania Achievements and challenges," Journal of Applied and Advanced Research, vol. 3, no. 4, p. 108-118, 2018.

[12] M. Doevenspeck, "Lake Kivu's methane gas: Natural risk, or source of energy and political security?," Afrika Spectrum: Deutsche Zeitschrift für Gegenwartsbezogene Afrikaforschung, vol. 42, no. 1, pp. 95-110, 2007.

[13] Uganda Bureau of Statistics, "Statistical Abstract," Uganda Bureau of Statistics, Kampala, 2019.

[14] E. Wasirwa, "LPG market conditions in Uganda," in WLPGA East Africa summit, Nairobi, 2011.
[15] A. Gupta and B. Gupta, "Sourcing of Natural Gas Through Cross Border Pipelines," in Natural Gas Markets in India, Singapore, Springer, 2017.

[16] UNDP/World Bank, Cross-Border Oil and Gas Pipelines: Problems and Prospects, UNDP/World Bank, 2003.

[17] U.S. Energy Information Administration, "eia: Independent Statistics and Analysis," 6 December 2019. [Online]. Available: https://www.eia.gov/energyexplained/natural-gas/.

[18] B. Babalwa, "ESI Africa: Africa's Power Journal," 27 August 2017. [Online]. Available: https://www.esiafrica.com/industry-sectors/business-and-markets/tanzania-towork-with-uganda-on-natural-gas-pipeline-project/.

[19] F. Hirslund, "An additional challenge of Lake Kivu in Central Africa - upward movement of the chemoclines," Journal of Limnology, vol. 71, no. 1, pp. 45-60, 2012.

[20] S. E. Pratt, "Earth: The Science Behind the Headlines," 18 August 2014. [Online]. Available: https://www.earthmagazine.org/article/benchmarks-august-151984-august-21-1986-african-killer-lakes-erupt.

[21] W. R. Jonathan, “MIT Technology Review,” 16 April 2015. [Online]. Available: https://www.technologyreview.com/2015/04/16/248915/lakekivus-great-gas-gamble/.

[22] OGJ Editors, "Exploration and Development," 28 June 2006. [Online]. Available: https://www.ogj.com/explorationdevelopment/article/17280869/ugandas-waxy-oil-flows-athigher-rate.

[23] Petroleum Authority of Uganda, "Uganda is not exporting crude oil," 25 January 2021. [Online]. Available: https://www.pau.go.ug/uganda-is-not-exporting-crude-oil/.

[24] Uganda Bureau of Statistics, "Statistical Abstract 2018," Uganda Bureau of Statistics, Kampala, 2018.

[25] T. Byakola, "Sustainable energy watch 2007 - Improving Energy Resilience in Uganda," 2007. [Online]. Available: http://helio-international.org/wpcontent/uploads/2013/12/Uganda.En-2007.pdf.

[26] pwc, "Creating Certainty: Uganda's FY 2013/14 Post Budget Analysis," 2013. [Online]. Available: https://www.pwc.com/ug/en/assets/pdf/uganda-budget2013.pdf.

[27] Globalpetrolprices.com, "GlobalPetrolPrices.com," 14 September 2020. [Online]. Available: https://www.globalpetrolprices.com/gasoline_prices/.

[28] World Nuclear Association, "World Nuclear Association," August 2018. [Online]. Available: https://www.worldnuclear.org/information-library/facts-and-figures/heat-valuesof-various-fuels.aspx.

[29] Ministry of Energy and Mineral Development, "Biomass Energy Strategy-Uganda,” UNDP, Kampala, 2015. 